\title{
Adsorption Behavior of Lead, Cadmium and Nickel on some Calcareous Soils
}

\author{
Sherine S. Mourid \\ Desert Research Center, Cairo, Egypt.
}

\begin{abstract}
THERE are many environmental factors that influence the mobility and bioavailability behavior of some heavy metals in soils. One of these factors is the content and form of calcium carbonate in soils. Experimental work has been carried out applying 1 and 3 mmole $(\mathrm{mM})$ of $\mathrm{Pb}, \mathrm{Cd}$ and $\mathrm{Ni}$ (in chloride forms) on 5 different calcareous soils from north coast area, Egypt. The adsorption of these elements at interval times from 1 to 168 hours was measured. Four kinetic models were applied: Elovich, Modified Frendlich, Horels and Diffusion equation.
\end{abstract}

The obtained results indicate that the adsorption process take three stages, a rapid rate from the starting time to about $2 \mathrm{hr}$, intermediate stage until about 100 hours and slow or steady rate until the end of reaction (168 hr). Comparing the adsorption process through the five soil samples can be arranged as follows; $S_{5}>S_{3}>S_{4}>S_{2}>S_{1}$. The retention of heavy metals depends on the amount of active calcium carbonate, clay content and surface area of the soil. The values of adsorbed three heavy metals on the five soil samples can be arranged as; $\mathrm{Cd}>\mathrm{Pb}>\mathrm{Ni}$.

The constants of the four kinetic equations $\left(a, b\right.$ and $\left.r^{2}\right)$ were compared for the two concentrations of each metal (Elovich, Modified Frendlich Equation "MFE", Horels and Diffusion). The correlation coefficient between soil criteria and the constants of the applied kinetic models reveals that highly positive correlation between active calcium carbonate, surface area and clay content with $\mathrm{a}$ and $\mathrm{b}$ constants in Elovich and Diffusion equations.

Keywords: Adsorption of heavy metals ( $\mathrm{Pb}, \mathrm{Cd}, \mathrm{Ni})$, Calcareous soils (Elovich, Modified Frendlich, Horels and Diffusion Equations).

The calcareous soils cover considerable areas in Egypt, particularly in the northern coast and Western Desert. They are roughly estimated to occur in $25 \%$ of the whole country. These calcareous soils are mainly originated from marine and lacustrine deposits, also weathered moderate rocks. The criteria of these soils are affected not only by the content of calcium carbonate but also the form of these carbonates in soil. These formations are recognized in the field as surface crust, subsurface face hardpan, nodules or concentrations or soft fine materials prevailing in soil profile. The presence of carbonates, either as $\mathrm{Ca}$ or $\mathrm{Mg}$ forms has great impact on the availability of nutrients for growing many 
plants, so nutrient amendments have to be followed through mineral or organic fertilizers for successive crop production.

Many of the calcareous areas are subjected to toxic elements contamination at different rates. The main sources of pollution by several elements such as $\mathrm{Pb}, \mathrm{Cd}$ and $\mathrm{Ni}$ are human activities either agricultural or industrial. The extensive application of mineral fertilizers which contain impurities of heavy metals, sewage sludge and disposal of wastes, sources of $\mathrm{Cd}$ contamination are the mining and smelting of $\mathrm{Pb}$ and $\mathrm{Zn}$, also the smokes besides the heavily traffic highways (Elbana and Selim, 2010).

Soil heavy metal pollution poses a risk to the environment and to human health (Roy and McDonald, 2014) due to bio-magnification (increases in metal concentration as the element passes from lower to higher trophic levels). Some of these elements can be essential for living organisms while some others are nonessential. Even concentrations of essential nutrients beyond a certain threshold will have pernicious health effects, as they interfere with the normal metabolism of living systems.

Lead is one of the most toxic heavy metals, as mention by Nordbery et al. (2007). It is widely used in many important industrial applications such as storage battery manufacturing, printing, pigments, fuels, photographic materials, and explosives manufacturing. The toxicity of lead to humans is well known; it replaces calcium and, consequently, can accumulate in the skeletal system (Anielak and Schmidt, 2011). Exposure to lead is associated with a wide range of effects, including various neurodevelopment effects, mortality (mainly due to cardiovascular diseases), impaired renal function, hypertension, impaired fertility and adverse pregnancy outcomes (WHO, 2011). The presence of aged cattle manure greatly increased $\mathrm{Pb}$ concentration in the leachate.

Nickel is one of the trace nutrients needed in the human body, but when ingested at high dosages, it can cause health problems like birth defects, embolism, and chronic bronchitis. Rothwell et al. (2007) showed that $\mathrm{Cu}, \mathrm{Ni}$, $\mathrm{Pb}, \mathrm{V}$ and $\mathrm{Zn}$ are leached from the contaminated peat soils into headwater streams. Mellis et al. (2004) found that the nickel adsorption decreased with elimination of organic matter.

The contamination of these toxic elements, at high rates, has tremendous hazardous impact on the environmental quality and all living organisms and human health.

The study of the adsorption behavior and retention of these heavy metals in calcareous soils is very important and attracted the attention of many researchers in many countries. Jalali and Moharrami (2007) investigate the competitive adsorption of trace elements in calcareous soils of western Iran. They mentioned that most sorption isotherms were well described by the Langmuir equation, also

Egypt. J. Soil Sci. 54, No. 4 (2014) 
$\mathrm{Zn}$ and $\mathrm{Ni}$ were the trace elements most strongly adsorbed by all soils, whereas $\mathrm{Mn}$ and $\mathrm{Cd}$ were the least adsorbed in the competitive situation.

Cadmium adsorption behavior in selected calcareous and acid soils from Iran was compared by Safarzadeh et al. (2009). Applying the kinetic models (Frendlich, Langmiur and Gunary) revealed that CEC and clay content were the most important soil properties affecting $\mathrm{Cd}$ adsorption behavior in calcareous soils, whereas in acid soils was $\mathrm{pH}$.

A recent publication by Fifi et al. (2013) on the assessing of mobility of lead, copper and cadmium, in a calcareous soil in Haiti, they concluded that at high metal concentrations, $\mathrm{Cd}$ may pose more threat to soils and ground water than $\mathrm{Pb}$ and $\mathrm{Cu}$.

With regards to Ni heavy metal (Adhami et al., 2008) investigated the adsorption characteristics of $\mathrm{Ni}$ as related to soil properties. Their results indicate that clay, $\mathrm{CEC}, \mathrm{OM}$ and $\mathrm{pH}$ are the main factors regulating $\mathrm{Ni}$ retention in the soils studied while calcium carbonate - equivalent does not significantly affect $\mathrm{Ni}$-retention. The sorption and desorption stirred - flour experiment was performed on the calcareous soil of central Italy by Businelli (2012) has drawn the following conclusion. The calcium carbonate presence in soil enhance $\mathrm{Ni}$ sorption, either by increasing its $\mathrm{pH}$ value that without aging promotes a $\mathrm{Ni}$ outer- sphere complication on negative charges of the soil surfaces or, more probably, forming a $\mathrm{Ni}$ complex on the calcite surface $\left(>\mathrm{CO}_{3} \mathrm{Ni}^{+}\right)$whose stability can support the hypothesis that it can be the main cause of the non reversible $\mathrm{Ni}$ retention in calcareous soils.

Das and Mondal (2011) tested and evaluated natural calcareous soil of India origin as a possible adsorbent for removal of lead from its aqueous solution using batch sorption technique. They found that the maximum removal occurred at $\mathrm{pH}$ 6.0. Equilibrium data fitted very well in the Langmuir isotherm equation confirming the monolayer adsorption capacity of $\mathrm{Pb}$ (II) ions onto calcareous soil.

The adsorption kinetics of $\mathrm{Cd}$ and $\mathrm{Zn}$ as influenced by some calcareous soil properties was investigated by Ghasemi-Fasaei and Jurrah (2013). Their results reveal that soil factors controlling $\mathrm{Zn}$ and $\mathrm{Cd}$ adsorption are almost similar which are mainly clay and organic matter. $\mathrm{Cd}$ adsorption rate was higher than that of $\mathrm{Zn}$ demonstrating higher capability of $\mathrm{Cd}$ in competition with $\mathrm{Zn}$ for occupying adsorption sites.

In some calcareous soils of Bostan area (west of Nile Delta) Elbana and Selim (2013) found that $\mathrm{Cd}$ retention exhibited strong non linear kinetic behavior and such strong sorption was accompanied by slow release with time. Moreover $\mathrm{Cd}$ was nearly immobile in surface soil whereas 30 and $20 \%$ of the applied $\mathrm{Cd}$ was mobile in the subsurface. 
The objective of these experimental works was conducted to determine the adsorption, retention and release of $\mathrm{Pb}, \mathrm{Cd}$ and $\mathrm{Ni}$ elements in some calcareous soils of Egypt. The comprehensive understanding of these processes is very beneficial to avoid the possible contamination with these toxic elements and their hazardous impact on plants and human health and consequently the means of remediation.

\section{Soil samples}

\section{Material and Methods}

Five soil samples were collected from surface soils $(0-30 \mathrm{~cm})$ of different field's locations in western north coastal and Mariut regions, northern of Egypt. The soils were air dried, crushed, and passed through a $2 \mathrm{~mm}$ sieve. Some physical and chemical properties of the soil samples including $\mathrm{pH}$, electrical conductivity (EC), calcium carbonate content $\left(\mathrm{CaCO}_{3}\right)$, active calcium carbonate, organic matter (OM), cation exchange capacity (CEC) and clay content were determined using standard methods mentioned by Cottenie et al. (1982) and Sparks (1998) and the results were presented in Table 1.

TABLE 1. The main criteria of the selected soil samples.

\begin{tabular}{|c|c|c|c|c|c|c|c|c|}
\hline $\begin{array}{c}\text { Soil } \\
\text { No }\end{array}$ & $\begin{array}{c}\mathbf{p H} \\
\mathbf{1 : 2 . 5}\end{array}$ & $\begin{array}{c}\mathbf{E C} \\
\mathbf{d s m}^{-\mathbf{1}}\end{array}$ & $\begin{array}{c}\mathbf{C a C O}_{\mathbf{3}} \\
\mathbf{\%}\end{array}$ & $\begin{array}{c}\text { Active } \\
\mathbf{C a C O}_{\mathbf{3}} \mathbf{\%}\end{array}$ & $\begin{array}{c}\mathbf{\text { OM }} \\
\mathbf{\%}\end{array}$ & $\begin{array}{c}\mathbf{C E C} \\
\mathbf{m q 1 0 0 g}^{-1}\end{array}$ & $\begin{array}{c}\text { Surface } \\
\mathbf{a r e a} \\
\mathbf{m}^{\mathbf{2}} \mathbf{g}^{-\mathbf{1}}\end{array}$ & $\begin{array}{c}\text { Clay } \\
\mathbf{\%}\end{array}$ \\
\hline 1 & 8.15 & 0.62 & 13.4 & 11.1 & 1.81 & 6.21 & 85.0 & 17.9 \\
\hline 2 & 8.10 & 6.65 & 20.2 & 5.1 & 0.87 & 5.57 & 27.5 & 5.1 \\
\hline 3 & 8.47 & 2.47 & 27.9 & 10.0 & 1.95 & 6.78 & 58.0 & 10.2 \\
\hline 4 & 8.50 & 0.22 & 34.9 & 2.5 & 1.27 & 3.62 & 12.4 & 2.8 \\
\hline 5 & 8.30 & 2.97 & 53.4 & 8.0 & 1.21 & 5.88 & 45.0 & 7.6 \\
\hline
\end{tabular}

Kinetic experiment

Heavy-metals in chloride form of $\left(\mathrm{PbCl}_{2}, \mathrm{CdCl}_{2}\right.$ and $\left.\mathrm{NiCl}_{2}\right)$ were used to obtain three aqua solutions of single component solutions, i.e., $\mathrm{Pb}, \mathrm{Cd}$ and $\mathrm{Ni}$ at fixed concentrations of 1 and $3 \mathrm{mM}$ prepared from these cations and kept for sorption study.

Adsorption experiments were carried out using Electrical Stirred Flow Unit (ESFU) method for the 5 soil samples. The system was vigorously shaken and the solution samples were taken after different periods; 1, 2, 6, 24, 48, 96 and 168 hours. at $25^{\circ} \mathrm{C}$ and analyzed according to Cottenie et al. (1982) by Atomic Absorption Spectrophotometer (AAS 200A Buck Scientific Model).

\section{Kinetics models}

In order to investigate the mechanism of sorption and potential rate controlling heavy metals transport and chemical reaction processes, both theoretical and empirical widely used kinetic models have been applied to test the experimental data. Equations presented in Table 2 were used to fit the data of three heavy metals under investigation.

Egypt. J. Soil Sci. 54, No. 4 (2014) 
TABLE 2. Equations used to study the adsorption of three heavy metals.

\begin{tabular}{|c|c|c|}
\hline Models & Equation & Description \\
\hline Elovich & $\mathrm{q}_{\mathrm{t}}=\mathrm{b}+(1 / \mathrm{a}) \ln \mathrm{t}$ & $\mathrm{q}_{\mathrm{t}}$ sorption capacity at time $\mathrm{t}$ in $\min$ \\
\hline $\begin{array}{l}\text { Modified } \\
\text { Freundlich equation }\end{array}$ & $\begin{array}{l}\mathrm{q}=\mathrm{bk}^{\mathrm{a}} \\
\log \mathrm{q}=\log \mathrm{b}+\mathrm{a}(\log \mathrm{t})\end{array}$ & $\begin{array}{l}\mathrm{t} \text { time in min } \\
\mathrm{a} \text { and } \mathrm{b} \text { constants }\end{array}$ \\
\hline Horel's & $\mathrm{q}=\mathrm{at}^{\wedge} \mathrm{b}^{*} \mathrm{e}^{\wedge}\left(\mathrm{C}^{*} \mathrm{t}\right)$ & \\
\hline Diffusion & $\begin{array}{l}1 / \mathrm{t}\left(\mathrm{Q}_{/} / \mathrm{Q}_{\infty}\right)= \\
4 / \mathrm{b}^{1 / 2}\left(\mathrm{a} / \mathrm{r}^{2}\right)^{1 / 2} \mathrm{I} / \mathrm{t}^{1 / 2}-\mathrm{a} / \mathrm{r}^{2}\end{array}$ & $\begin{array}{l}\mathrm{Q}_{\mathrm{t}}: \text { quantity of diffusing substance } \\
\mathrm{Q}_{\infty}: \text { is the corresponding quantity after } \\
\text { infinite time, } \\
\mathrm{r}: \text { radius of the cylinder }\end{array}$ \\
\hline
\end{tabular}

Thus the constants can be obtained from the slope and intercept of the linear plot of $\mathrm{q}_{\mathrm{t}}$ versus $\ln \mathrm{t}$. Equations will be used to test the applicability of each equation to the kinetics of each heavy metal (II) sorption on soils.

\section{Results and Discussion}

Adsorption of the heavy metals on calcareous soils

The concentrations of $\mathrm{Pb}, \mathrm{Cd}$ and $\mathrm{Ni}$ heavy metals on 5 calcareous soils as a result of applying these metals in 1 and $3 \mathrm{mM}$ are illustrated in Fig.1. It is obvious from the obtained results that the adsorption of these heavy metals was enhanced by the elevated the levels of added solution from 1 to $3 \mathrm{mM}$ for the three elements. Similar results were reported by Elbana and Selim (2010) and (2013).

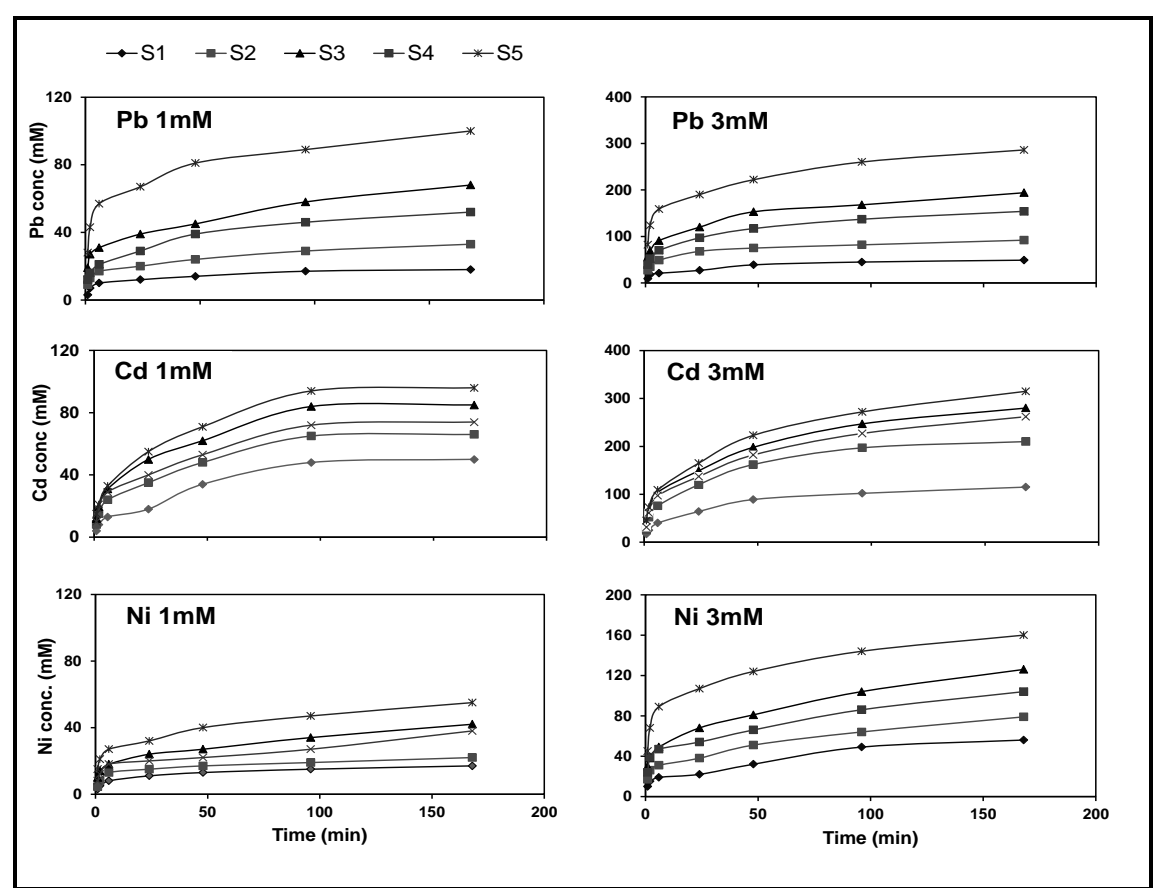

Fig. 1. The concentrations of adsorbed heavy metals on the calcareous soils.

Egypt. J. Soil Sci. 54, No. 4 (2014) 
As a time factor, adsorption isotherm takes three stages, a rapid process from the starting time to about $2 \mathrm{hr}$, intermediate stage until about $100 \mathrm{hrs}$ and after that, steady rate until the end of reaction (168 hr).

Comparing the adsorption of the three metals in the five soil samples which have different content of total and active $\mathrm{CaCO}_{3}$, clay percent and consequently the total surface area (Table 1) regardless the adsorbed element, the rate of concentration can be arranged as followed;

$$
\mathrm{S}_{5}>\mathrm{S}_{3}>\mathrm{S}_{4}>\mathrm{S}_{2}>\mathrm{S}_{1}
$$

This proves that the total content of $\mathrm{CaCO}_{3}$ is not the limiting factor in the adsorption and retention processes but the active fraction and the clay content are more effective.

Also the values of adsorbed elements indicate that; $\mathrm{Cd}>\mathrm{Pb}>\mathrm{Ni}$ in the five soil samples, for example in $S_{5}$ they are 315,286 and $160 \mathrm{mM}$ at the end of reaction applying $3 \mathrm{mM}$ of added solution. The higher capability of $\mathrm{Cd}$ in competition with other elements in occupying adsorption sites on clay calcium carbonate and organic matter are the main reason of its high adsorption. In this respect Ghasemi-Fasaei and Jurrah (2013) refereed to competition between Cd and $\mathrm{Zn}$ adsorption.

\section{Adsorption kinetics of the heavy metals}

To assess the retention and mobility behavior of $\mathrm{Pb}, \mathrm{Cd}$ and $\mathrm{Ni}$ in the five calcareous soil samples, under investigation, four kinetic models were applied. The parameters of these estimated equations (Elovich, Modified Freundlich Equation (MFE), Horels and Diffusion) for two concentrations (1 and $3 \mathrm{mM}$ ) are recorded in Tables 3, 4 and 5 for $\mathrm{Pb}, \mathrm{Cd}$ and $\mathrm{Ni}$ metals respectively.

Comparing the isotherm results of the 5 soil samples (Table 3 ) it is found that the constants $\mathrm{a}, \mathrm{b}$ and $\mathrm{r}^{2}$ of Elovich equation can be arranged as followed for the lead element in 2 concentrations:

$$
\mathrm{S}_{5}>\mathrm{S}_{3}>\mathrm{S}_{4}>\mathrm{S}_{2}>\mathrm{S}_{1}
$$

These constants of MFE ( $\left.a, b, r^{2}\right)$ have very slight variations between the five calcareous soil samples $(\mathrm{a}=1.98$ to $1.06, \mathrm{~b}=0.30-0.28)$ in $\mathrm{Pb}_{3}$. The values of the (a) parameters in Horels model is the highest in $S_{1}>S_{2} \& S_{4}>S_{3} \& S_{5}$ (range between 0.25 to 0.33 ). High figures were obtained for the diffusion equation, the constants a, b are maximum in $\mathrm{S}_{5}>\mathrm{S}_{3}>\mathrm{S}_{4}>\mathrm{S}_{2}>\mathrm{S}_{1}$.

According to the higher coefficient of determination $r^{2}$ and the lowest standard error SE, data presented in Tables 3, 4 and 5, the kinetics models under investigation could be arranged as follows, MFE was the best in describing the kinetic data followed by Horels model, Elovich and for less extent diffusion equation. It should be mention that increasing the application rate of pollutants applied to the soil samples didn't influenced the studied constants. These obtained results are in agreement with Safarzadeh et al. (2009) who applied Freundlich, Langmuir and Gunary Kinetic model and found that CEC and clay 
content were the most important soil properties which influence $\mathrm{Cd}$ adsorption in calcareous soil.

TABLE 3. The estimated parameters of the kinetic models to assess adsorption behavior of lead.

\begin{tabular}{|c|c|c|c|c|c|c|c|c|}
\hline \multirow[b]{2}{*}{ Constants } & \multicolumn{2}{|c|}{ Elovich } & \multicolumn{2}{|c|}{ M.F.E } & \multicolumn{2}{|c|}{ Horels } & \multicolumn{2}{|c|}{ Diffusion } \\
\hline & $\mathrm{Pb}_{1}$ & $\mathrm{~Pb}_{3}$ & $\mathbf{P b}_{1}$ & $\mathbf{P b}_{3}$ & $\mathbf{P b}_{1}$ & $\mathrm{~Pb}_{3}$ & $\mathbf{P b}_{1}$ & $\mathrm{~Pb}_{3}$ \\
\hline & \multicolumn{8}{|c|}{ Soil No 1} \\
\hline $\mathrm{a}$ & 4.14 & 9.23 & 0.65 & 1.06 & 0.39 & 0.33 & 1.11 & 3.2 \\
\hline $\mathrm{b}$ & 2.71 & 7.46 & 0.30 & 0.30 & 1.41 & 2.41 & 5.30 & 11.7 \\
\hline$r^{2}$ & 0.97 & 0.96 & 0.87 & 0.93 & 0.90 & 0.94 & 0.88 & 0.9 \\
\hline \multirow[t]{2}{*}{ SE } & 0.95 & 3.38 & 0.11 & 0.07 & 0.24 & 0.13 & 21.71 & 87.8 \\
\hline & \multicolumn{8}{|c|}{ Soil No 2} \\
\hline $\mathrm{a}$ & 8.91 & 26.77 & 1.01 & 1.47 & 0.34 & 0.28 & 1.86 & 5.2 \\
\hline $\mathrm{b}$ & 4.30 & 12.52 & 0.23 & 0.23 & 2.31 & 3.35 & 10.24 & 32.1 \\
\hline$r^{2}$ & 0.97 & 1.00 & 0.97 & 0.98 & 0.97 & 0.99 & 0.96 & 0.9 \\
\hline \multirow[t]{2}{*}{ SE } & 1.73 & 1.20 & 0.04 & 0.03 & 0.04 & 0.01 & 17.77 & 355.9 \\
\hline & \multicolumn{8}{|c|}{ Soil No 3} \\
\hline $\mathrm{a}$ & 17.51 & 49.17 & 1.31 & 1.76 & 0.20 & 0.25 & 3.82 & 11.3 \\
\hline $\mathrm{b}$ & 8.56 & 26.37 & 0.22 & 0.24 & 3.05 & 4.05 & 19.49 & 57.8 \\
\hline$r^{2}$ & 0.93 & 0.98 & 0.97 & 1.00 & 0.98 & 1.00 & 0.98 & 1.0 \\
\hline \multirow[t]{2}{*}{ SE } & 5.08 & 8.32 & 0.04 & 0.01 & 0.03 & 0.01 & 31.37 & 663.3 \\
\hline & \multicolumn{8}{|c|}{ Soil No 4} \\
\hline $\mathrm{a}$ & 9.55 & 34.68 & 1.10 & 1.62 & 0.29 & 0.28 & 3.35 & 9.4 \\
\hline $\mathrm{b}$ & 7.71 & 22.02 & 0.28 & 0.26 & 2.52 & 3.71 & 11.82 & 42.1 \\
\hline$r^{2}$ & 0.97 & 0.99 & 0.99 & 0.99 & 0.99 & 1.00 & 0.97 & 1.0 \\
\hline \multirow[t]{2}{*}{ SE } & 3.12 & 5.53 & 0.02 & 0.02 & 0.01 & 0.01 & 40.01 & 471.9 \\
\hline & \multicolumn{8}{|c|}{ Soil No 5} \\
\hline $\mathrm{a}$ & 30.72 & 87.48 & 1.52 & 1.98 & 0.26 & 0.25 & 5.42 & 15.6 \\
\hline $\mathrm{b}$ & 13.00 & 36.97 & 0.22 & 0.22 & 3.47 & 4.54 & 35.86 & 101.1 \\
\hline$r^{2}$ & 0.98 & 0.98 & 0.95 & 0.96 & 0.96 & 0.96 & 0.91 & 0.9 \\
\hline SE & 3.48 & 10.69 & 0.05 & 0.04 & 0.05 & 0.04 & 354.5 & 2248.3 \\
\hline
\end{tabular}

Correlation coefficient have been estimated between soil properties of the five samples and the parameters of the kinetic equations ( $a$ and $b$ ) for the two concentrations of each heavy metal under consideration.

The data illustrated in Fig. 2-4 represents the values of $(a)$ constants for the three heavy metals under consideration. Regarding the other constants have the same trend as $(a)$ constants; it is not necessary to illustrate the data in figures.

The (a) constant which represents the rate of pollutant release from calcareous soil or the intensity factor showed that increasing the application rate applied to calcareous soils led to increase the rate of pollutant release from the studied soils. Regarding the (b) contrast, data showed that in most cases the capacity factor represented by $(b)$ constant gave the same trend with increasing the rate of release. 
TABLE 4. The estimated parameters of the kinetic models to assess adsorption behavior of cadmium.

\begin{tabular}{|c|c|c|c|c|c|c|c|c|}
\hline \multirow[b]{2}{*}{ Constants } & \multicolumn{2}{|c|}{ Elovich } & \multicolumn{2}{|c|}{ M.F.E } & \multicolumn{2}{|c|}{ Horels } & \multicolumn{2}{|c|}{ Diffusion } \\
\hline & $\mathrm{Cd}_{1}$ & $\mathrm{Cd}_{3}$ & $\mathbf{C d}_{1}$ & $\mathrm{Cd}_{3}$ & $\mathbf{C d}_{1}$ & $\mathrm{Cd}_{3}$ & $\mathrm{Cd}_{1}$ & $\mathrm{Cd}_{3}$ \\
\hline & \multicolumn{8}{|c|}{ Soil No 1} \\
\hline $\mathrm{a}$ & 2.70 & 10.97 & 0.68 & 1.28 & 0.51 & 0.43 & 4.10 & 8.3 \\
\hline $\mathrm{b}$ & 9.20 & 19.52 & 0.48 & 0.37 & 1.55 & 2.88 & 1.89 & 17.6 \\
\hline$r^{2}$ & 0.91 & 0.98 & 0.97 & 0.99 & 0.97 & 1.00 & 0.96 & 0.95 \\
\hline \multirow[t]{2}{*}{ SE } & 6.38 & 5.98 & 0.08 & 0.04 & 0.15 & 0.01 & 95.31 & 441.0 \\
\hline & \multicolumn{8}{|c|}{ Soil No 2} \\
\hline $\mathrm{a}$ & 5.33 & 20.36 & 1.00 & 1.53 & 0.47 & 0.47 & 5.00 & 15.47 \\
\hline $\mathrm{b}$ & 11.64 & 36.44 & 0.40 & 0.39 & 2.24 & 3.44 & 9.10 & 33.27 \\
\hline$r^{2}$ & 0.96 & 0.98 & 0.97 & 0.96 & 0.98 & 0.98 & 0.95 & 0.94 \\
\hline \multirow[t]{2}{*}{ SE } & 4.85 & 10.42 & 0.07 & 0.07 & 0.08 & 0.08 & 176.01 & 1848.0 \\
\hline & \multicolumn{8}{|c|}{ Soil No 3} \\
\hline $\mathrm{a}$ & 8.18 & 25.83 & 1.15 & 1.64 & 0.44 & 0.45 & 6.35 & 20.07 \\
\hline $\mathrm{b}$ & 14.89 & 46.62 & 0.38 & 0.38 & 2.58 & 3.71 & 13.29 & 40.74 \\
\hline$r^{2}$ & 0.97 & 0.98 & 0.98 & 0.96 & 0.99 & 0.98 & 0.94 & 0.96 \\
\hline \multirow[t]{2}{*}{ SE } & 5.24 & 15.10 & 0.05 & 0.07 & 0.03 & 0.09 & 308.7 & 1893.2 \\
\hline & \multicolumn{8}{|c|}{ Soil No 4} \\
\hline $\mathrm{a}$ & 7.58 & 23.83 & 1.09 & 1.60 & 0.43 & 0.45 & 5.43 & 18.65 \\
\hline $\mathrm{b}$ & 12.64 & 43.19 & 0.37 & 0.38 & 2.46 & 3.63 & 11.68 & 37.30 \\
\hline$r^{2}$ & 0.97 & 0.97 & 0.97 & 0.96 & 0.98 & 0.97 & 0.95 & 0.98 \\
\hline \multirow[t]{2}{*}{ SE } & 5.11 & 14.86 & 0.06 & 0.07 & 0.08 & 0.10 & 200.8 & 1474.1 \\
\hline & \multicolumn{8}{|c|}{ Soil No 5} \\
\hline $\mathrm{a}$ & 8.95 & 30.32 & 1.21 & 1.72 & 0.43 & 0.41 & 7.19 & 22.36 \\
\hline $\mathrm{b}$ & 16.77 & 51.49 & 0.37 & 0.36 & 2.73 & 3.91 & 14.46 & 45.72 \\
\hline$r^{2}$ & 0.97 & 0.97 & 0.99 & 0.99 & 1.00 & 0.99 & 0.95 & 0.97 \\
\hline SE & 6.44 & 19.03 & 0.03 & 0.04 & 0.01 & 0.03 & 350.2 & 1692.6 \\
\hline
\end{tabular}

The obtained data illustrated in Fig. 2,3 and 4 indicate the following conclusion:

- The a and b constants in Elovich and Diffusion models are highly positive correlated with active calcium carbonated content $(2.5-11.9 \%)$, surface area $(12-85 \mathrm{ml})$ and clay percent $(2.8-12.9 \%)$. The same trend in the three concentrations of the heavy metals $\mathrm{Pb}, \mathrm{Cd}$ and $\mathrm{Ni}$.

- The (a) constant in Freundlich equation has also significant correlation with these soil criteria.

- The influence of organic matter content of these calcareous samples have positive correlation (range between significant and non significant) with (a and b) constants in Elovich and Diffusion models for $\mathrm{Pb}, \mathrm{Cd}$ and $\mathrm{Ni}$.

- The low values of EC $\left(0.22-6.65 \mathrm{dsm}^{2}\right)$ have negative relation with the constants ( $\mathrm{a}$ and $\mathrm{b}$ ) in Elovich and Diffusion equations.

Egypt. J. Soil Sci. 54, No. 4 (2014) 
- The increase of the concentration of the added heavy metal (1 and $3 \mathrm{mM})$ has no influence on the correlation between soil parameters and the constants of kinetic equations applied for the adsorption trend of each of $\mathrm{Pb}$, $\mathrm{Cd}$ and $\mathrm{Ni}$.

TABLE 5. The estimated parameters of the kinetic models to assess adsorption behavior of nickel.

\begin{tabular}{|c|c|c|c|c|c|c|c|c|}
\hline \multirow[b]{2}{*}{ Constants } & \multicolumn{2}{|c|}{ Elovich } & \multicolumn{2}{|c|}{ M.F.E } & \multicolumn{2}{|c|}{ Horels } & \multicolumn{2}{|c|}{ Diffusion } \\
\hline & $\mathrm{Ni}_{1}$ & $\mathrm{Ni}_{3}$ & $\mathrm{Ni}_{\mathbf{1}}$ & $\mathrm{Ni}_{3}$ & $\mathrm{Ni}_{\mathbf{1}}$ & $\mathrm{Ni}_{3}$ & $\mathrm{Ni}_{1}$ & $\mathrm{Ni}_{3}$ \\
\hline & \multicolumn{8}{|c|}{ Soil No 1} \\
\hline $\mathrm{a}$ & 3.03 & 6.23 & 0.57 & 1.02 & 0.39 & 0.25 & 1.10 & 3.82 \\
\hline $\mathrm{b}$ & 2.64 & 8.29 & 0.32 & 0.31 & 1.25 & 2.41 & 4.08 & 7.45 \\
\hline$r^{2}$ & 1.00 & 0.86 & 0.95 & 0.95 & 0.97 & 0.97 & 0.92 & 0.97 \\
\hline \multirow[t]{2}{*}{ SE } & 0.32 & 7.17 & 0.06 & 0.07 & 0.06 & 0.80 & 12.50 & 49.96 \\
\hline & \multicolumn{8}{|c|}{ Soil No 2} \\
\hline $\mathrm{a}$ & 5.59 & 14.16 & 0.78 & 1.27 & 0.35 & 0.23 & 1.26 & 4.86 \\
\hline $\mathrm{b}$ & 3.09 & 10.76 & 0.27 & 0.27 & 1.72 & 2.96 & 6.95 & 16.35 \\
\hline$r^{2}$ & 0.97 & 0.91 & 0.90 & 0.97 & 0.92 & 0.97 & 0.87 & 0.99 \\
\hline \multirow[t]{2}{*}{ SE } & 1.10 & 7.19 & 0.09 & 0.05 & 0.14 & 0.45 & 30.07 & 38.71 \\
\hline & \multicolumn{8}{|c|}{ Soil No 3} \\
\hline $\mathrm{a}$ & 8.79 & 23.02 & 1.03 & 1.48 & 0.24 & 0.24 & 2.48 & 7.78 \\
\hline $\mathrm{b}$ & 5.59 & 17.42 & 0.25 & 0.27 & 2.39 & 3.43 & 10.19 & 26.99 \\
\hline$r^{2}$ & 0.94 & 0.94 & 0.98 & 0.99 & 0.99 & 1.00 & 0.98 & 0.99 \\
\hline \multirow[t]{2}{*}{ SE } & 2.94 & 9.72 & 0.03 & 0.02 & 0.02 & 0.00 & 13.47 & 43.83 \\
\hline & \multicolumn{8}{|c|}{ Soil No 4} \\
\hline $\mathrm{a}$ & 7.74 & 23.06 & 0.97 & 1.44 & 0.23 & 0.22 & 2.11 & 6.03 \\
\hline b & 4.73 & 13.45 & 0.25 & 0.25 & 2.25 & 3.35 & 8.80 & 26.02 \\
\hline $\mathbf{r}^{2}$ & 0.88 & 0.91 & 0.93 & 0.94 & 0.93 & 0.95 & 0.94 & 0.97 \\
\hline \multirow[t]{2}{*}{ SE } & 3.74 & 9.10 & 0.06 & 0.06 & 0.10 & 0.08 & 37.07 & 129.7 \\
\hline & \multicolumn{8}{|c|}{ Soil No 5} \\
\hline $\mathbf{a}$ & 14.22 & 48.18 & 1.22 & 1.72 & 0.23 & 0.25 & 3.12 & 8.75 \\
\hline b & 7.15 & 20.79 & 0.23 & 0.22 & 2.80 & 3.93 & 16.29 & 55.96 \\
\hline $\mathbf{r}^{2}$ & 0.96 & 0.98 & $\begin{array}{l}0.98 \\
\end{array}$ & 0.96 & 0.98 & 0.96 & 0.97 & 0.93 \\
\hline SE & 3.14 & 5.57 & 0.03 & 0.04 & 0.03 & 0.04 & 36.52 & 738.3 \\
\hline
\end{tabular}

\section{Conclusion}

The comprehension understanding of adsorption and mobility processes of heavy metals is very important to avoid the hazardous impact of these toxic elements to environmental quality and human health. The role of calcium carbonate in the soil is very effective on the adsorption of $\mathrm{Pb}, \mathrm{Cd}$ and $\mathrm{Ni}$. The fine participate form of $\mathrm{CaCO}_{3}$ as active portion in the process of adsorption more than the total content. The variation between the individual elements on the adsorption and retention depends mainly on the radios number and electro charges of each heavy metal. The values of adsorbed elements proved that $\mathrm{Cd}>$ $\mathrm{Pb}>\mathrm{Ni}$, due to the higher capacity of $\mathrm{Cd}$ on occupying the adsorption sites on clay, calcium carbonate and organic matter. 

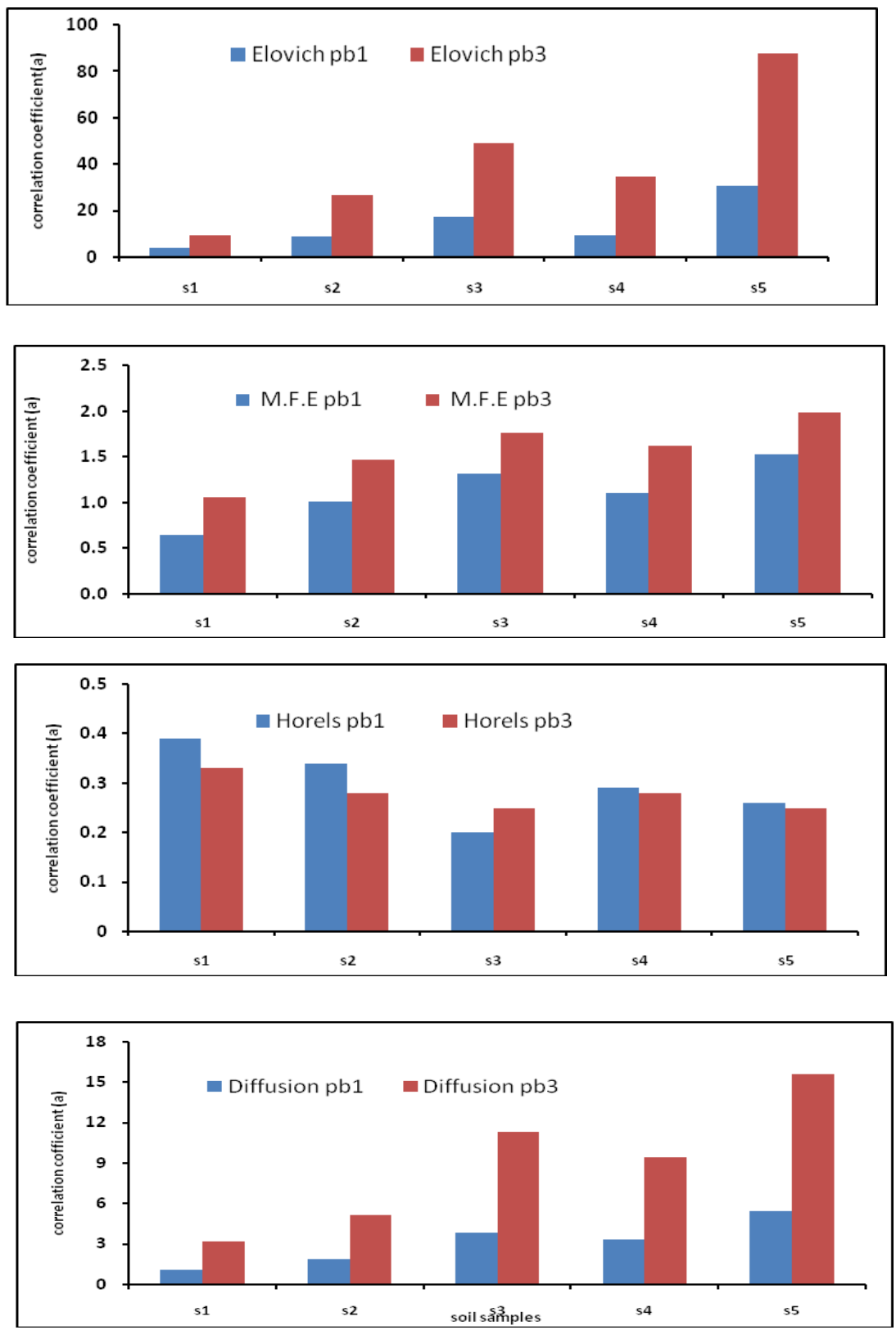

Fig.2. The correlation coefficient (a) between soil samples and lead contents by different kinetics models.

Egypt. J. Soil Sci. 54, No. 4 (2014) 

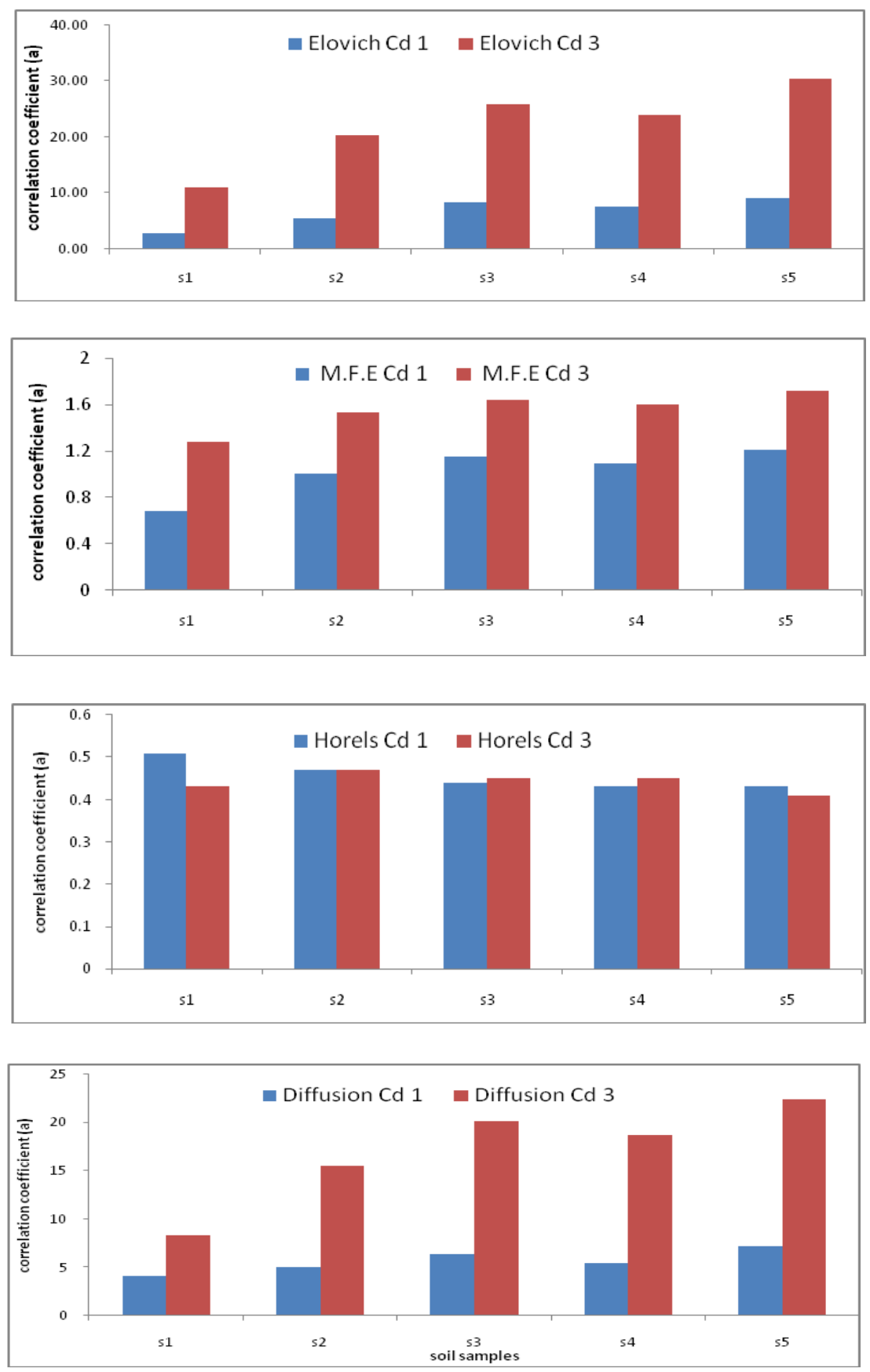

Fig. 3. The correlation coefficient (a) between soil samples and cadmium contents by different kinetics models. 

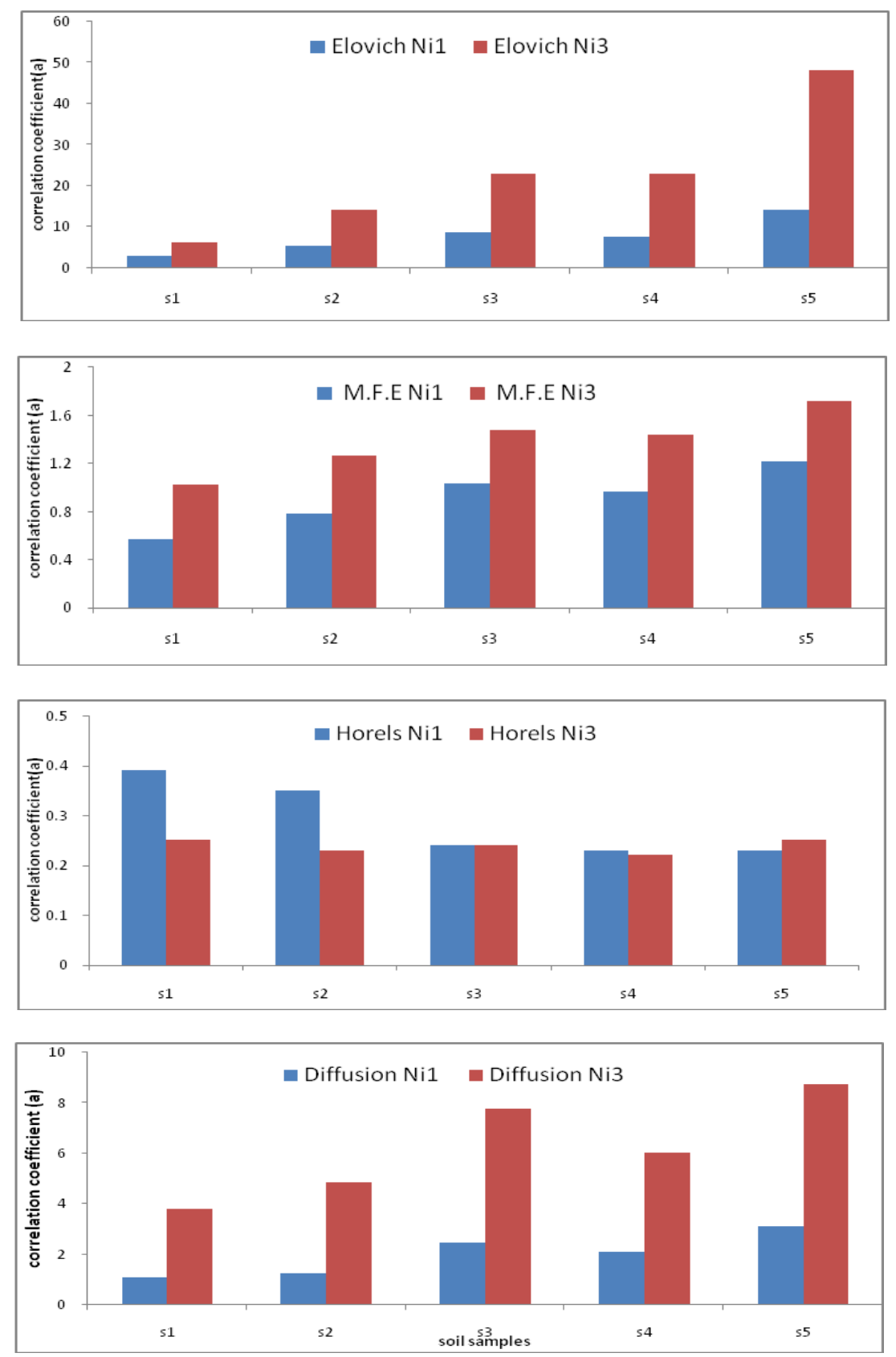

Fig. 4. The correlation coefficient (a) between soil samples and nickel contents by different kinetics models.

Egypt. J. Soil Sci. 54, No. 4 (2014) 


\section{References}

Adhami , E., Salmanpour, A. , Omindi, A., Khosravi, N., Ghasemi-Fasaei, R. and Maftoun, M. (2008) Nickel adsorption characteristics of selected soils as related to some soil properties. Soil \& Sediment Contamination 17: 643-653.

Anielak, A.M. and Schmidt, R. (2011) Sorption of lead and cadmium cations on natural and manganese-modified zeolite. Polish J. Environ. Stud. 20: 15- 19.

Businelli, D. (2012) Effect of carbonates and organic matter in retention and release of Nickel by a central Italy soil. Soil Sci.177: 236-240.

Cottenie, A., Verloo, M., Kiekens,L., Velgh, G. and Camcrlynck, R. (1982) "Chemical Analysis of Plant and Soil. Anal.”, Agrochem., State Univ., Ghent, Belgium.

Das, B. and Mondal, N. K. (2011) Calcareous soil as new adsorbent to remove lead from aqueous solution: Equilibrium, kinetic and thermodynamic study. Univ. J. Environ. Res. and Technol. 1: 515-530.

Elbana, T. A. and Selim, H. M. (2013) Lead mobility in calcareous soils: Influence of cadmium and copper. Soil Sci. 178: 417-424.

Elbana, T. A. and Selim, H. M. (2010) Cadmium transport in alkaline and acidic soils: Miscible displacement experiments. Soil Sci. Soc. Am. J. 74: 1956 -1966.

Fifi, U., Winiarski, T. and Emmanue, E. (2013) Assessing the mobility of lead, copper and cadmium in a calcareous soil port-au prince, Haiti. Inter. J. Environ. Res. Public Health 10: 5830-5843.

Ghasemi-Fasaei, R. and Jurrah, M. (2013) Adsorption kinetics of cadmium and zinc as influenced by some calcareous soil properties. Inter. J. Agric. and Crop Sci. 5: 479483.

Jalali, M. and Moharrami, S. (2007) Competitive adsorption of trace elements in calcareous soils of western Iran. Geoderma 140: 156-163.

Mellis, E.V., Cruz, M.C. and Casagrande, J.C. (2004) Nickel adsorption by soils in relation to $\mathrm{pH}$, organic matter and iron oxides. Scientia-Agricola. 61: 190-195.

Nordbery, G.F., Fowler, B.A., Nordbery, M. and Friberg. L.T. (2007) "EDS Handbook on the Toxicology of Metals", $3^{\text {rd }}$ ed., Elsevier, Amsterdam.

Roy, M. and McDonald, L. M. (2014) Metal uptake in plants and health risk assessments in metal-contaminated smelter soils. Land Degradation and Development.

Rothwell, J. J., Evans, M.G., Daniels, S. M. and Allott, T. E. (2007) Baseflow and stormflow metal concentrations in streams draining contaminated peat moorlands in the Peak District National Park (UK). J. Hydrology 341: 90-104.

Safarzadeh, S., Ronaghi, A. and Karimaian, N. (2009) Comparison of cadmium adsorption behavior in selected calcareous and acid soils. Iran Agric. Res. 28: 63-76. 
Sparks, D.L. (1998) "Soil Physical Chemistry", $2^{\text {nd }}$ ed., Lewis Publishers, CRC Press, London.

WHO (2011) “Guidelines for Drinking Water Quality”, $4^{\text {th }}$ ed., WHO Press, Geneva.

(Received 9/4/2014;

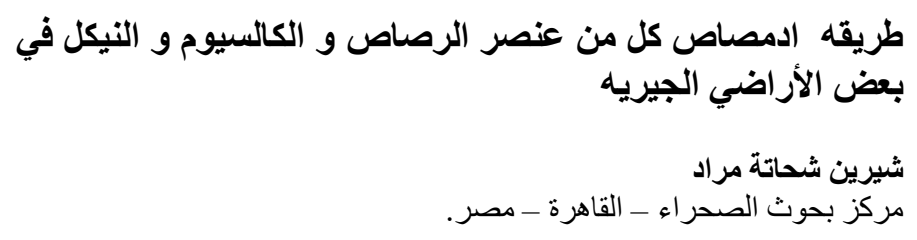

تؤثر العو امل البيئية المختلفه في تحرك و تفاعل و مدي قابليه العناصر الثقيله

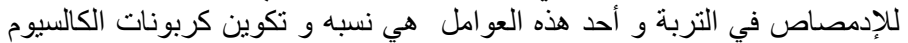

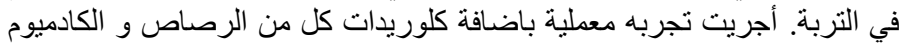

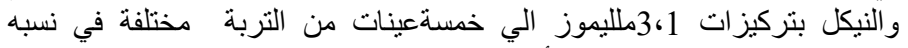

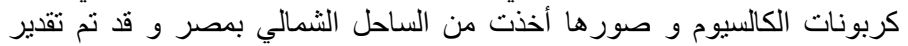

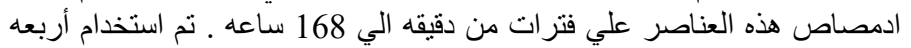

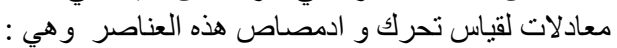

Elovich, Modified Freundlich, Horels and Diffusion Equation.

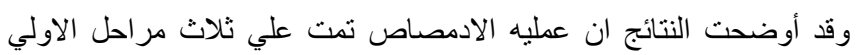

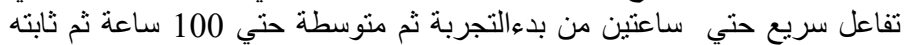

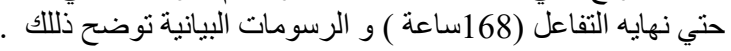

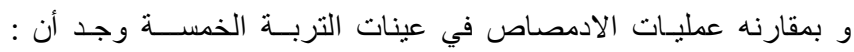
مما يدل علي ان ادمصاص هذه العناصر الثقيله يتوقف

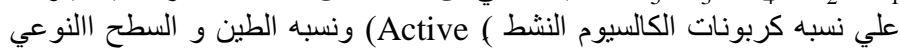

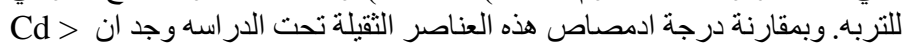
$\mathrm{Pb}>\mathrm{Ni}$

وقد تم حساب معامل الارتباط Correlation coefficient بين ثوابت الابت

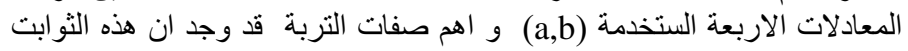

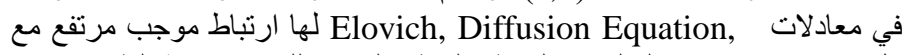
كل من نسبه كربونات الكالسيوم النشط و السطح النوعي للتربه و نسبة الطين. 